\title{
Attitude of Student, Teacher Behaviour and Class Management: A Study
}

\author{
S M Tazuddin., Assistant professor Business Administration Dept., Cantonment College Jashore
}

\begin{abstract}
Attitude is one of the most important factors in helping to get through the highs and lows of life. Since attitude spells how a person copes, whatever perspective you may hold will invariably have an effect in your performance and the way you and secondary data collected from various secondary sources. In any teaching-learning situation, teacher plays an handle rejection. This study based on both primary and secondary data. Primary data collected from survey method important role in the classroom management. This study focused on the student's attitude, teacher's behavior and classroom management. This study showed elements of student's attitude and socialization is made up of eight stages of psychosocial development. And also mention seven mental disorders of childhood. This research explains some principles and techniques of classroom management and discipline. This study reveals that teacher activities in classroom to maintain well management in classroom. Finally, the research gives some suggestion and recommendation to overcome barriers in classroom management.
\end{abstract}

\section{INTRODUCTION}

In a changing society, it is very important to get acquainted with new knowledge and science and to keep in touch with modern education and management techniques to survive in the competitive job market. In addition, due to technological advancement, attitude, study and teaching strategies have changed.

Attitude is what influences all our actions. People persevere at activities they believe are possible. Convinced they have the ability to complete a task, they are willing to attempt it. Uncertain, or sure of their own inability, they will defer to others instead. Attitudes are taught. We communicate our judgments of others' abilities in many ways. If we are in positions of authority (parent, teacher, instructor), our attitudes shape others' opinions of their own abilities, and thus their willingness to act. Teachers have known for years that the student who is taught he or she could outperform those taught they cannot; that expectations shape performance.

At one time the teaching method was teacher centric. At present it has changed and the teaching method is becoming student centered. However, student-centered teaching or participatory teaching methods are being strengthened in secondary schools. In the field of higher education, especially in colleges, most of the teaching methods are teacher-centered. Where the teacher plays the main role during the teaching. However, there is no valid reason to think that the student will play a completely passive role if the teaching process is implemented following a teacher-centered approach. The role of the teacher is very important to enliven the teaching process using the teacher-centered approach. However, if the students do not try to understand or follow what the teacher says with their entire limbs alert, then the role of the teacher, no matter how important, Teaching is bound to fail there. So the role of the student is also in the teachercentered teaching method, but the role of the student is not the main one there. In that teaching method the role of the teacher is primary and the role of the student is secondary, That teaching method has been prevalent in our country for a long time. That is why this teacher-centered teaching method has been termed as traditional. Appropriate classrooms and a conducive environment are needed for the smooth conduct of teaching activities. Classroom management plays an important role in making learning practical. All the functions of the school are crucial in creating a good learning environment for the overall layout of the classroom. Students spend most of their time in the classroom as long as they stay in school. So the overall environment of the classroom is quite influential. Classroom management in the general sense refers to the learning process of students in the classroom in the light of the curriculum. It is not possible to introduce a good teaching and modern teaching method without proper class discipline and class management. So the teaching method is heartwarming to the student, In order to make it information-based and interesting, teachers need to focus on classroom management. Class management is the process of making teaching effective through appropriate methods and techniques and taking measures to manage effective lessons. According to academics, Class management is very important to provide balanced and quality education to all the students of the country. Empowerment and control of teachers in the classroom will be collaborative. By introducing participatory teaching-learning methods, the teacher will reduce his monopoly in the classroom by assigning partial responsibility to the student's teaching and learning. In this process, under the supervision of the teacher, students acquire knowledge of student-student and teacher-student interaction. Any flaws in classroom management will hinder the successful implementation of this modern method of teaching and learning. Therefore, classrooms in educational institutions should be arranged and arranged in such a way that the classroom becomes easily attractive to the students. It is necessary to create a classroom that is as pleasant and attractive as the children feel comfortable in their own home. The classrooms will be clean and tidy. The four walls of the classroom will be decorated with pictures of different scholars or education related charts, open racks or glass cupboards with various models and other teaching 
materials, a sufficient number of books, magazines and periodicals which will be open for the use of students. In the current era of globalization, the modern teaching method will be completely IT based teachers will teach students in multimedia classrooms through projectors. In the schools / colleges of the developed world, the teaching activities have to be continued in line with the way the teachers have been teaching. The modern teaching method is to conduct up-to-date teaching by eliminating the old meditative ideas.

\section{THEORETICAL FRAMEWORK}

\section{Attitude}

Attitude is the way of thinking or feeling of a person towards something. Attitude can be positive and negative such as my friends are always sympathetic or selfish. An individual's personal feelings about a subject or event are considered attitudes. S.P Robbins said- Attitude or evaluation statement either favourable or unfavourable concerning people, objects, or event. Attitude develop from the surrounding environment, it is not a kind of education. Attitude are caught, rather than taught.

\section{Teacher's behaviour}

Teacher's behaviour is defined as the behaviour or activities of persons as they go about doing whatever is required of teachers, particularly those activities that are concerned with the direction of guidance of the learning of others.

\section{Class management}

Class management refers to the activities that are carried out in the classroom in order to successfully implement the learning process of the students in the light of the curriculum.

\section{METHODOLOGY}

The paper has been based on mostly descriptive in nature. To complete the study in the light of research objectives, information both from primary and secondary source were considered necessary. Both primary and secondary data been used in the study. The primary data collected by using survey method. And secondary data have been collected from journal, published report, various books and internal article. A brief literature review was conducted for identifying the studies that are associated with analysis of student attitude, class management and teacher behaviour.

\section{OBJECTIVES}

The objectives of the study are:

To know the attitude, teacher behaviour, elements of attitude and eight stages of psychosocial development

$>$ To find out some mental disorders of childhood

$>$ To know principles and find out some techniques of classroom management \& discipline

$>$ To give some suggestion and recommendation to overcome its barriers.

\section{DISCUSSION}

\section{A. The element of attitude:}

Attitudes are formed with three different religious but interdependent elements towards an object. These are: Emotions, information and behaviour. Also a few more elements are currently given special importance.

Emotional: Emotional elements of an attitude include a person's feelings for an object and the tendency to like or dislike that object. People love nature. In this case the attitude towards nature is emotional.

$>$ Informative: The informational element of an attitude is based on a person's belief or information about an object. Whether a belief or information is wrong or not, such cognitive ideas are considered part of his attitude.

$>$ Behavioural: The tendency of a person to behave in a certain way towards an object is a matter of the behavioural element of attitude. When a person behaves favourably or unfavourably towards something, then the nature of the person's attitude is understood.

$>$ Logical element: Argument affects people's attitudes. People are forced to change their attitudes if they can be dealt with irrefutable reasoning, even if they have some beliefs or ideas. That is reasoning affects attitudes.

> Campaign: According to Goebbels, Hitler's propaganda adviser repeatedly spreading a lie is accepted as true. In the same way, whatever the truth of the incident, the attitude of the people is affected by the continuous propaganda.

\section{B. Attitude of students:}

Child psychology involves the psychological, social, educational and development of a Child from birth to adulthood. The changes and experience that take place in every moment of life are child psychology. Such changes or experience occur in a child, especially within three age ranges, the first is between one and three years of age, the second is between three and seven years of age and the third is between seven and the youngest age.

Every step of the child's personality development requires the help of teachers, parents and relatives. The family can play a special role in the development of the child. Teachers, parents can play an important role in the process of socialization of the child. German psychologist E.H Erikson explains psychosocial theory in his book childhood and society. According to him, the social and emotional development of children and adolescents continues till adulthood. According to him, socialization is made up of eight conditions. There are eight stages of psychosocial development:

Basic beliefs and disbelief: This stage is from birth to 18 months as the initial stage of the child's personality development. At this level Children are helpless and completely dependent on their parents. If the child gets affectionate love and necessary care, faith is born in him and he feels safe in the world. And if he 
doesn't get love and care, he feels insecure and mistrusts everyone.

$>$ Freedom, Shame and suspicious: This level ranges from 18 months to three years. Good parental care makes children proficient in personal control. At this stage the child can recognize himself and is proud of him. Children feel ashamed when their parents or others interrupt them to work independently. So at this stage children should focus on choice and independence.

$>$ Enthusiasm and guilt: The range of this level is from 3 years to 5 years. Children who are properly cared for by these parents. Expand their thinking and imagination through active play. Learns to help others and also to accept leadership. Children are intimidated by the lack of proper care, team members become completely dependent on one room and adults and play and thinking skills are disrupted.

$>$ Perseverance and inferiority: The range of this level is from 6 years to 12 years. At this level children acquire compatibility with different aspects of the environment and master new behaviours and experience. As a result of acquiring new tasks and experience, the child's tendency to work hard and their desire to enjoy satisfaction and success is enhanced.

$>$ Conflict of sense of identity and role: The range of this level is puberty that is from 13 years to 19 years. At this stage students realize their individuality and their own. Those who receive appropriate encouragement through personal inquiry develop from this step. Those who are not managed properly fail to control themselves. They can't have a clear idea about themselves.

$>$ Intimacy and solidarity and loneliness: Since this range from 20 to 24 years, Ericsson calls it early age.

$>$ Productivity and stillness: The age of development of this society of personality is 25 to 64 years. This is the best time for productivity. Productivity can be about creating something through good work.

Fullness and despair: The duration of this level is from 15 years before death. At this level the fullness of the ego comes so it is called Integrity. If peers are good, the child develops empathy, Cooperation, tolerance and leadership qualities.

\section{Some mental disorders of childhood:}

Children receive various aspects of their use and development from their parents, teachers and other people in the society. Most children have problems with inattention but there are some problems that do not seem normal in General. Then you must take the help of child psychologists. Below are some common childhood mental disorders:

$>$ Attention deficit hyperactivity disorder ( A.D.H.D): It is most often seen in children. Common symptoms of this. Type of Mental disorder is excessive, inattention, impossibility of distance, and arrogant, angry, irritable crying etc.
Depression and bipolar disorder: A common symptom of this type of problem is a sudden change in mood, a lot of laziness, anger and crying etc.

$>$ Anxiety disorder: Such children are terribly worried and scared. At one point this amount of fear or anxiety increases so much that they cannot sleep at night.

$>$ Asperger's syndrome: Although this mental problem is not completely autism, it can be considered as a partial problem of autism. All these children are not very social and do not like much change in increasing the pace of their daily life, can't look straight into the eyes, strange verbal and physical gestures have no sympathy and hand or foot movement is very low.

> Learning disability: Such children cannot learn easily because they can not concentrate on anything. Even their ability to remember is very low and they're unable to determine the direction.

$>$ Disruptive behaviour disorder: Such children feel a different kind of satisfaction by warming up to other children. Even going to a social event is a lot of fun by breaking the rules or vandalizing things. They can even lie and steal.

$>$ Eating disorder: Children with this type of problem usually have a condition called bulimia. They usually have a kind of picky batik or thought that playing anything will make them gain weight or look bad. As a result they cannot eat or vomit after playing a little.

\section{Principles and Techniques of Classroom Management and Discipline}

Classroom management is an important aspect of teacher teaching. Principles and Techniques of Classroom Management \& Discipline are required to know the principles of class management, practical techniques and classroom management. He has been taking classes for a long time but he is not able to control the class at all. Or he is a new teacher but not trained. Eeffective classroom management is conducive to proper reading comprehension. Teachers need to be very conscious in this regard in terms of class equipping and maintaining class discipline. There are a variety of strategies for implementing classroom management.

$>$ Class management strategies:

- Class room sorting techniques: Arranging the classroom is an important issue for the class teacher. Half of the success of class control depends on this. Here are some things to keep in mind when arranging classrooms:

$\checkmark$ Adequate lighting and ventilation.

$\checkmark$ Class room size.

$\checkmark$ Furniture suitable for seating students

$\checkmark$ Proper placement of board

$\checkmark$ Arrange the equipment

$\checkmark$ A secluded environment

$\checkmark$ Healthy environment 
- Administrative management strategies:

$\checkmark$ Record student attendance

$\checkmark$ Instruct students to enter the classroom

$\checkmark$ Observe student behavior before, during, and after the class.

$\checkmark$ Controlling unwanted behavior.

$\checkmark$ Ensuring seating arrangements for students.

$\checkmark$ Monitor regular attendance

$\checkmark$ Instruct students in individual, pair and group work.

- Strategies for using helpful learning materials:

$\checkmark$ Prepare lesson related learning materials.

$\checkmark$ Save learning materials.

$\checkmark$ Ensure the use of all learning resources.

- Teaching-learning management strategies:

$\checkmark$ Maintain the position and movement of the teacher in the classroom.

$\checkmark$ Creating a pleasant atmosphere in the classroom.

$\checkmark$ Apply appropriate methods and techniques related to the lesson.

$\checkmark$ To create interest in learning and to be active.

$\checkmark$ Use text related materials.

$\checkmark$ Following the correct strategy in asking questions

$\checkmark$ Paying attention to students.

\section{> Teacher Activities in Classroom}

Before starting teaching activities in the classroom, the teacher needs to be careful about whether the classroom management is appropriate. The planned educational activities suitable for classroom and requires the favorable environment. The tasks that a teacher will perform in the classroom at the beginning of the teaching practice are:

$\checkmark$ Exchange greetings with students.

$\checkmark$ Silently look at all the students.

$\checkmark$ Start class activities as soon as possible.

$\checkmark$ Provide necessary materials among the students.

$\checkmark$ Asking student's questions.

$\checkmark$ Divide students into groups if necessary.

$\checkmark$ Controlling the conversations of the surrounding students.

$\checkmark$ Encourage every student about the lesson and draw students' attention.

$\checkmark$ Pay equal attention to the students on the right, left, front and back of the classroom.

$\checkmark$ Care should be taken not to influence any particular student or group.

$\checkmark$ Creating opportunities for more student participation and speaking in group work

$\checkmark$ Encourage all students to raise their hands and draw the teacher's attention.

$\checkmark$ Creating a collaborative environment to build confidence among all students

\section{$>$ Classroom Discipline}

The effectiveness of classroom teaching depends on classroom management. For this the teacher needs to be tactful and special care, otherwise all the labor can turn into wasteful labor. Classroom Discipline is an essential part of class management. $\checkmark$ The class teacher will determine the place of seating considering the age, height, and visual impairment etc. of the students.

$\checkmark$ The teacher will always give advice and help the class leader to maintain class discipline.

$\checkmark$ The position of the teacher in the classroom should be such that he can easily keep an equal eye on all the students. For no reason should he hide behind blackboards, maps or educational materials.

$\checkmark$ Teachers will make proper use of time while teaching. He will strive to teach with joy and keep the student active.

$\checkmark$ Fluent eloquence, lively lesson presentation is a useful element of class discipline. Opposes the teaching of regional language teachers.

$\checkmark$ Teacher vision is one of the best ways to maintain class discipline. Sweet personality is the characteristic of a teacher. Vision is one of the expressions of his sweet personality.

$\checkmark$ Inattentive students can be made attentive by asking abrupt questions, behaviors can be restrained.

\section{SUGGESTIONS AND RECOMMENDATIONS}

There may be some unwanted situations while teaching in the classroom, which can create obstacles in the way of proper teaching. The preventive measures that the teacher will take to deal with such a situation are called preventive class management. The strategies to be adopted are outlined below-

> Student Classroom Entry: Some students may enter the classroom after the commencement of the teaching activities and may cause confusion over the issue of taking seats. This can cause disruption in teaching. The teacher will efficiently take appropriate action in this regard.

> Student seating arrangement: The teacher will complete the seating arrangement of the students in the classroom before starting the lesson. In this case, the teacher has to arrange the seating considering the height, age and less and more merit of the students.

$>$ Attention: Students may be in a state of chaos before the main subject is taught in the classroom. In this case, the teacher will use some techniques to get the student's attention. Have a good exchange with the students first and ask some questions from the previous lesson so that the students will avoid the chaos and concentrate on the lesson.

> Student Attendance: Attendance activities of students in the classroom help to restore order in the classroom. So taking attendance before lessons can be a strategy of class management.

$>$ Attracting students' attention while teaching: Teaching in a lecturing manner can cause some chaos in the classroom. In this case, not all students pay attention to the teacher's speech. In that case ask questions related to the lesson in the class to draw the attention of all the students to the lesson. Students will be aware of this and will be in control of the class. 
Assignment and acceptance of work in the classroom: In order to keep the students busy in the classroom and to participate in the lesson, they have to work in groups. This will ensure the participation of all the students in the lesson and the students will complete the assigned work with attention. Later you have to collect work from everyone.

$>$ Appreciating the work of students: Appreciation is a psychological reward for students. The expectation of receiving this award is in everyone. So students need to appreciate the work in the classroom. In this way students will be attached to education and will avoid chaotic attitude through self-purification.

$>$ The qualities that students need to be good people:

- Religious discipline must be followed.

- One should take care of one's own behaviour and actions so that no one else gets upset.

- No one can be harmed financially or in any other way.

- If possible, you have to benefit others.

- Do not lie, follow the right path.

So the teacher has to keep the above points in mind to avoid unwanted topics. Many unwanted topics can arise in the classroom, especially for trainee teachers. Since, they are not experienced and skilled teachers. In this case, it is necessary to deal with all these with the wisdom and strategy of the teachers and build a proper class management. Because of the importance of classroom in conducting formal lessons is immense.

\section{CONCLUSION}

We need to have far reaching objective direction in our education system. Which can instil in students a sense of tradition revolving around self-confidence, values freedom, ideological aspirations and the application of healthy cultural and intellectual sacrifices? If the desired qualities of the character of the individual are not inculcated through education then the education system will prove to be a failure. The teacher gives the main encouragement to the students to get involved in social welfare work. Through close observation in the classroom, the teacher will discover the direction and tendency of the student's happiness and guide him on the path to success. In order to inculcate the human virtues, truthfulness and neutrality in the individual and even citizen, it is necessary to spread religious education along with other teachings that are conducive to the creation of moral values in the students.

\section{REFERENCES}

[1]. Ferguson (2001). Co-Curricular Activities : A Pathway to Careers, JG Ferguson Publishing Company, United States .

[2]. Haynes, A. (2010). The Complete Guide to Lesson Planning and Preparation, Continuum International Publishing Group, New York .

[3]. Gagne, R.M. (1974). The Conditions of Learning.3rd.ed. Holt, Rinehart e Wilson.
[4]. Gibbons, P. (2002). Scaffolding language scaffolding learning. Portsmouth, NH. Heinemann.

[5]. LIEBMAN. J. (1988). Teaching Operation Research: Lesson from Cognitive Psychology. Interfaces.

[6]. Ajzen, I., \& Fishbein, M. (1980). Understanding attitudes and predicting social behaviour. Englewood Cliffs, NJ: Prentice-Hall.

[7]. Cubberley, E. P.(1916), Public School Administration; A Statement of the Fundamental Principles Underlying the Organization and Administration of Public Education, New York, Houghton Mifflin Co.

[8]. Hanson, E.M.(1979). Educational Administration and Organizational Behavior, Boston : Allyn \& Bacon.

[9]. Taylor, F.W. (1911). The Principles of Scientific Management, New York : Harper Bros.

[10]. Taylor, F.W. (1919). Shop Management, New York: Harper \& Row.

[11]. Reeder, W. G. (1958). Fundamentals of School Administration, Macmillan.

[12]. Fayol H.(1944). General and Industrial Management, Ran Constance Storrs, London : Sir Isaac Pitman and Sons.

[13]. Adams, D., Nelson, R., \& Todd, P. (1992). Perceived usefulness, ease of use, and usage of information technology: A replication. MIS Quarterly, 16(2), 227247.

[14]. Agarwal, R., \& Karahanna, E. (2000). Time flies when you're having fun: Cognitive absorption and beliefs about information technology usage. MIS Quarterly, 24(4), 665-694.

[15]. Ajzen, I., \& Fishbein, M. (1977). Attitude-behaviour relations: A theoretical analysis and review of empirical research. Psychological Bulletin, 84(5), 888-918.

[16]. Bobbitt, F. (1913). 'The Supervision of City Schools', In Yearbook of the National Safety for the Study of (NSSE), Chicago, pp. 43-49.

[17]. Heffron,F.and Feeley,N.M. (1983). The Administrative Regulatory Process, New York: Longman.

[18]. Collado, M. D. C. \& Atxurra, R. L. (2006). 'Democratic Citizenship in Textbooks in Spanish Primary Curriculum', Journal of Curriculum Studies, 38(2), p. 209-210.

[19]. Newlin, M., Lavooy, M., \& Wang, A. (2005). An experimental comparison of conventional and webbased instructional formats. North American Journal of Psychology, 7(2), 327-335.

[20]. M. (2008). Online technologies self-efficacy and selfregulated learning as predictors of final grade and satisfaction in college-level online courses. American Journal of Distance Education, 22(2), 72-89.

[21]. Rabe-Hemp, C., Woollen, S., \& Humiston, G. (2009). A comparative analysis of student engagement, learning, and satisfaction in lecture hall and online learning settings. Quarterly Review of Distance Education, 10(2), 207-218. 
[22]. Saadé, R. G. (2007). Dimensions of perceived usefulness: Toward enhanced assessment. Decision Sciences Journal of Innovative Education, 5(2), 289310.

[23]. Saadé, R. G., \& Bahli, B. (2005). The impact of cognitive absorption on perceived usefulness and perceived ease of use in online learning: An extension of the technology acceptance model. Information \& Management, 42(2), 317-327. 